\title{
Isolation and use of eight phages for typing Yersinia enterocolitica $\mathrm{O} 3$
}

\author{
Y. KAWAOKA*, T. MITANI, K. OTSUKI and M. TSUBOKURA \\ Department of Veterinary Microbiology, Faculty of Agriculture, Tottori University, Tottori-shi, Tottori 680, \\ Japan
}

Summary. Subdivision of 137 isolates of Yersinia enterocolitica $\mathrm{O} 3$ into eight phagovars has been achieved. Some geographical differences were found in the sources of these phagovars and also of two biovars.

\section{Introduction}

The species Yersinia enterocolitica was subdivided by Nicolle et al. (1973) into 10 phagovars (I to X) with 12 phages (I to XII). Amongst $55 \mathrm{O}$-serovars of $Y$. enterocolitica, $\mathrm{O} 3$ was the most frequent isolate from patients in many countries except North America (Aldová and Lázničková, 1979; Alonso et al., 1979; Vandepitte and Wauters, 1979; Shayegani et al., 1981; Zen-yoji, 1981; Bottone, 1983). There are also four biovars of $Y$. enterocolitica, distinguishable by their action on D-xylose and lecithin, and their production of indole (Wauters, 1970; Brenner, 1981). Most O3 strains are biovar 4 and belong to phagovar VIII or IX of Nicolle et al. (1973). The O3 strains of phagovar VIII have been isolated in Europe (Aldová and Lázničková, 1979) and Japan (Tsubokura et al., 1982; Fukushima et al., 1984), and those of phagovar IX in South Africa (Nicolle et al., 1973) and Canada (Toma and Lafleur, 1981). Moreover, O3 strains have been isolated from various animals: man, pigs, dogs, cats, monkeys and rats (Hurvell, 1981). Except for North America, the strains isolated in any one country have been thought to belong to only one biovar and phagovar (Shayegani et al., 1981; Toma and Lafleur, 1981; Bottone, 1983). Further subdivision seemed desirable epidemiologically.

\section{Materials and methods}

\section{Bacteria}

We received 137 isolates of $Y$. enterocolitica $\mathrm{O} 3$, of various origins (table IV), from Drs D. P. Falcao, H.

Received 8 May 1986; revised version accepted 30 Oct. 1986.

* Correspondence should be sent to DrY.Kawaoka, Department of Virology and Molecular Biology, St. Jude Children's Research Hospital, 332 N. Lauderdale, P.O. Box 318, Memphis, TN 38101 , USA.
Fukushima, W. Knapp, H. J. Koomhof, T. Maruyama, H. H. Mollaret, G. Wauters and S. Winblad. They were identified as $Y$. enterocolitica by their positive reactions with urea, ornithine, sucrose, maltose and cellobiose, and negative reactions for L-rhamnose, melibiose, raffinose, $\mathrm{KCN}$ and Voges-Proskauer (Brenner, 1981).

\section{Medium}

In all tests, bacteria were cultivated on nutrient-agar plates (Kawaoka et al., 1983).

\section{Isolation of phages}

The samples from which phages were isolated are shown in table I. Faeces $(1 \mathrm{~g})$ was suspended in $10 \mathrm{ml}$ of nutrient broth. The suspended faeces and other samples were centrifuged at $10000 \mathrm{rpm}$ for $10 \mathrm{~min}$, and the supernates were filtered $(0.45 \mu \mathrm{m}$ Millipore $)$. Phage isolation was attempted by direct plating of the filtrate $(0.1 \mathrm{ml})$ and a suspension of the propagating bacterium $\left(10^{8}\right.$ cells, $\left.0.1 \mathrm{ml}\right)$ in $0.5 \%$ soft agar. When phage was not isolated by direct plating, the same specimen $(1 \mathrm{ml})$ was mixed with an overnight culture $(5 \mathrm{ml})$ of a propagating strain in nutrient broth. After incubation for $24 \mathrm{~h}$ at $25^{\circ} \mathrm{C}$, a few drops of chloroform were added, and the culture was shaken vigorously and then centrifuged. A $0.1-\mathrm{ml}$ portion of the aqueous phase was mixed with bacterial suspension $\left(10^{8}\right.$ cells, $\left.0.1 \mathrm{ml}\right)$ and $0.5 \%$ soft agar $(3 \mathrm{ml})$ and poured on to a nutrient agar plate. Unless quite different plaques were detected on this plate, only one plaque was picked. The phages were cloned more than three times by plaque isolation.

Phages I to XII of Nicolle et al. (1973) were obtained from $\operatorname{Dr} \mathrm{H}$. H. Mollaret. They were propagated as described previously (Kawaoka et al., 1982).

\section{Phage typing}

Of 28 phages that were isolated, eight were selected because of their stability and propagating ability. Their propagating strains and origins are shown in table $\mathrm{I}$. 
Table I. Origins and propagating strains of phages

\begin{tabular}{|c|c|c|}
\hline Phage* & Origin & $\begin{array}{l}\text { Propagating strain } \dagger \text { of } \\
Y . \text { enterocolitica (serovar) }\end{array}$ \\
\hline HM-1 & raw sewage & Ye $3827(\mathrm{O} 3)$ \\
\hline HM-3 & raw sewage & MY 79 (O9) \\
\hline HR-1 & river water & Ye 3827 (O3) \\
\hline HM-2 & raw sewage & Ye 3827 (O3) \\
\hline HU-I & raw sewage & Ye 3827 (O3) \\
\hline HC-2 & chicken faeces & Ye 135 (O1) \\
\hline HS- 6 & raw sewage & Ye 135 (O1) \\
\hline HT-3 & raw sewage & Ye 135 (O1) \\
\hline
\end{tabular}

* The phages were isolated by direct plating, or after preliminary propagation, at $25^{\circ} \mathrm{C}$ (see text).

$\dagger$ The three propagating strains were received from $\mathrm{Dr} \mathbf{H}$. $\mathrm{H}$. Mollaret.

Phage-typing was performed with the routine test dilution of the phage (highest dilution that gives confluent lysis of its propagating strain), as described previously (Tsubokura et al., 1982). The phages were spotted on a lawn of the test culture and the plates were incubated for $24 \mathrm{~h}$ at $25^{\circ} \mathrm{C}$.

\section{Serotyping}

Strains were serotyped by slide-agglutination with cross-adsorbed $\mathrm{O}$-antisera.

\section{Biochemical tests}

Each strain was tested at $25^{\circ} \mathrm{C}$ for biochemical characteristics sufficient to identify the species and to determine its biovar. Carbohydrates were examined up to 7 days; action on amino acids and citrate, and the Voges-Proskauer reaction, were recorded at 4 days.

\section{Results}

The phage susceptibility of 137 isolates of $Y$. enterocolitica $\mathrm{O} 3$ revealed eight different patterns (table II) which enabled us to designate eight new phagovars ( 1 to 8 ) of serovar O3. This permitted further subdivision of each of four phagovars previously described by Nicolle et al. (table III). In conjunction with their phagovars, we have defined nine groups (A to I) within serovar O3.

Table IV shows that although $90(66 \%)$ of our 137 isolates belonged to group A, the others could be differentiated into eight groups. The 16 strains of group B were isolated mainly in Japan, and constituted $25 \%$ of the 61 Japanese isolates. Similarly, all 15 strains of groups F, G, H and I were from Japan. In contrast, the 13 strains of groups D and E came from Brazil, France, South Africa and Sweden, but not from Japan.

Thus, there was a difference in geographical distribution of the phagovars of $Y$. enterocolitica O3. Moreover, this difference in distribution was apparent even when the isolates were divided only into their two biovars: the 122 isolates of biovar 4 came from various countries, only 46 of them from Japan, whereas all 15 of the biovar 3 isolates were from Japan (tables III and IV).

\section{Discussion}

Baker and Farmer (1982) developed a phagetyping system for inter-species differentiation of $Y$. enterocolitica, $Y$. kristenseni, $Y$. frederikseni and $Y$. intermedia; but this was not suitable for subdivision of $Y$. enterocolitica $\mathrm{O} 3$.

The phage set established in the present investigation subdivided strains of $Y$. enterocolitica $\mathrm{O} 3$

Table II. Designation of eight phagovars of $Y$. enterocolitica $\mathrm{O} 3$ by the range of phages that lysed them

\begin{tabular}{c|ccccccccc}
\hline & \multicolumn{8}{|c}{ Lysis with phage } \\
\cline { 2 - 8 } $\begin{array}{c}\text { Yhagovar of } \\
\text { Y. enterocolitica } 03\end{array}$ & HM-1 & HM-3 & HR-1 & HM-2 & HU-1 & HC-2 & HS-6 & HT-3 \\
\hline 1 & + & + & + & + & + & - & - & - \\
2 & + & + & + & + & + & - & + & - \\
3 & + & + & - & + & + & - & - & - \\
4 & + & + & + & - & + & - & - & - \\
5 & + & + & + & + & - & + & - & - \\
6 & + & + & + & + & + & + & - & - \\
7 & + & - & - & - & - & - & - & - \\
8 & - & - & - & - & - & + & + & + \\
\hline
\end{tabular}

$+=$ Confluent lysis $;-=$ no lysis or incomplete lysis. 
Table III. Grouping of Y. enterocolitica $\mathrm{O} 3$

\begin{tabular}{cccc}
$\begin{array}{c}\text { Biovar* of } \\
\text { Y. enterocolitica }\end{array}$ & $\begin{array}{c}\text { Phagovart of } \\
\text { Y.enterocolitica }\end{array}$ & $\begin{array}{c}\text { O3 } \\
\text { phagovar } \ddagger\end{array}$ & $\begin{array}{c}\text { O3 } \\
\text { group§ }\end{array}$ \\
\hline 4 & VIII & 1 & A \\
4 & VIII & 2 & B \\
4 & VIII & 3 & C \\
4 & IX & 1 & D \\
4 & IX & 4 & E \\
3 & II & 5 & F \\
3 & II & 6 & G \\
3 & X & 7 & H \\
3 & X & 8 & I \\
\hline
\end{tabular}

* Wauters, 1970.

$\dagger$ Nicolle et al., 1973.

$\ddagger$ Our designation (table II).

$\S$ Our designation, by derivation from the other columns.

into eight phagovars. In conjunction with the previous phagovars of Nicolle et al. (1973), this has enabled us to designate nine groups, A to I (table III). Recently we have shown the biochemical heterogeneity of O3 strains isolated in Japan (Fukushima et al., 1984). The present study showed that this serovar is even more heterogeneous in phage susceptibility; and our nine new groups may be useful epidemiologically.

In spite of extensive studies, the mode of transmission and other epidemiological features of $Y$. enterocolitica infection have not been fully elucidated. The number of $\mathrm{O} 3$ strains tested in this study is not sufficient to establish a firm correlation between origin and phage type. However, some geographical differences were found (table IV). Japan was the country of origin of all our isolates of groups F, G, H and I, and of most of our group $B$ isolates, whereas our South African isolates were of groups D and $\mathrm{E}$ which correspond to phagovar IX of Nicolle et al. (1973). This finding is consistent with those of previous studies (Nicolle et al., 1973; Toma and Lafleur, 1981) in which phagovar IX was found mainly in Canada and South Africa. Unfortunately, we could not examine the Canadian strains; it would be interesting to know which of our nine groups occur in that country.

We thank Drs D. P. Falcao (UNESP-Campus de Araraguara, Brazil), H. Fukushima (Public Health Institute of Shimane Prefecture, Japan), W. Knapp (Universitat Erlangen-Nurnberg, Germany), H. J. Koomhof (South African Institute for Medical Research, South Africa), T. Maruyama (Tokyo Metropolitan Research Laboratory of Public Health, Japan), H. H. Mollaret (Pasteur Institute, France), G. Wauters (Universite Catholique de Lourain, Belgium) and S. Winblad (University of Lund, Sweden) for providing strains of $Y$. enterocolitica $\mathrm{O} 3$, and Lisa Wilson for typing the manuscript. This work was supported partly by a Grant-in-Aid for Scientific Research from the Ministry of Education, Science and Culture of Japan.

Table IV. Relationship between origin and $\mathrm{O} 3$ group in 137 strains of $Y$. enterocolitica $\mathrm{O} 3$

\begin{tabular}{|c|c|c|c|c|c|c|c|c|c|c|}
\hline \multirow{2}{*}{\multicolumn{2}{|c|}{$\begin{array}{l}\text { Origin } \\
\text { Country }\end{array}$}} & \multicolumn{9}{|c|}{$\begin{array}{c}\text { Number of strains of } Y \text {. enterocolitica } \mathrm{O} 3 \text { in each of our newly } \\
\text { designated O3 groups* }\end{array}$} \\
\hline & & A & B & $\mathrm{C}$ & D & $\mathrm{E}$ & $\mathbf{F}$ & $\mathrm{G}$ & $\mathrm{H}$ & I \\
\hline Man & $\begin{array}{l}\text { Japan } \\
\text { France } \\
\text { Sweden } \\
\text { South Africa } \\
\text { Hungary } \\
\text { West Germany } \\
\text { Belgium } \\
\text { Brazil }\end{array}$ & $\begin{array}{r}21 \\
10 \\
10 \\
10 \\
7 \\
7 \\
5\end{array}$ & 4 & 2 & $\begin{array}{l}1 \\
1 \\
5\end{array}$ & 5 & & 5 & & \\
\hline Pig & $\begin{array}{l}\text { Japan } \\
\text { Belgium } \\
\text { Brazil }\end{array}$ & $\begin{array}{l}6 \\
6 \\
1\end{array}$ & 4 & & & & 4 & 3 & & 1 \\
\hline Dog & Japan & 3 & 5 & & & & & 1 & & \\
\hline Cat & Japan & 1 & 2 & & & & & & & \\
\hline $\begin{array}{l}\text { Monkey } \\
\text { Rat }\end{array}$ & $\begin{array}{l}\text { Brazil } \\
\text { Brazil }\end{array}$ & 3 & & & & 1 & & & & \\
\hline River water & Japan & & & & & & & & 1 & \\
\hline Total & & 90 & 16 & 3 & 7 & 6 & 4 & 9 & 1 & 1 \\
\hline
\end{tabular}

* see table III. 


\section{REFERENCES}

Aldová E, Lázničková K 1979 Comments on the ecology and epidemiology of Yersinia enterocolitica in Czechoslovakia. Contributions to Microbiology and Immunology 5: 122-131.

Alonso J M, Bercovier H, Servan J, Mollaret H H 1979 Contribution to the study of the ecology of Yersinia enterocolitica in France. Contributions to Microbiology and Immunology 5:132-143.

Baker P M, Farmer J J 1982 New bacteriophage typing system for Yersinia enterocolitica, Yersinia kristensenii, Yersinia frederiksenii, and Yersinia intermedia: correlation with serotyping, biotyping, and antibiotic susceptibility. Journal of Clinical Microbiology 15:491-502.

Bottone E J 1983 Current trends of Yersinia enterocolitica isolates in the New York City area. Journal of Clinical Microbiology 17:63-67.

Brenner D J 1981 Classification of Yersinia enterocolitica. In: Bottone E J (ed) Yersinia enterocolitica, CRC Press, Boca Raton FL pp. 1-8.

Fukushima H, Tsubokura M, Otsuki K, Kawaoka Y 1984 Biochemical heterogeneity of serotype O3 strains of 700 Yersinia strains isolated from humans, other mammals, flies, animal feed, and river water. Current Microbiology $11: 149-154$

Hurvell B 1981 Zoonotic Yersinia enterocolitica infection: host range, clinical manifestations, and transmission between animals and man. In : Bottone $\mathrm{E} J$ (ed) Yersinia enterocolitica, CRC Press, Boca Raton FL, pp. 145-159.

Kawaoka Y, Otsuki K, Tsubokura M 1982 Characteristics of Yersinia enterocolitica bacteriophages. Zentralblatt für Bak- teriologie Mikrobiologie und Hygiene 1 Abteilung Originale A 253: 102-109.

Kawaoka Y, Otsuki K, Tsubokura M 1983 Growth temperaturedependent variation in the bacteriophage-inactivating capacity and antigenicity of Yersinia enterocolitica lipopolysaccharide. Journal of General Microbiology 129:27392747.

Nicolle P, Mollaret H H, Brault J 1973 Recherches sur la lysogenie, la lysosensibilite, la lysotypie et la serologie de Yersinia enterocolitica. Contributions to Microbiology and Immunology 2: 54-58.

Shayegani M, Deforge I, McGlynn D M, Root T 1981 Characteristics of Yersinia enterocolitica and related species isolated from human, animal, and environmental sources. Journal of Clinical Microbiology 14:304-312.

Toma S, Lafleur L 1981 Yersinia enterocolitica infection in Canada 1966 to August 1978. In: Bottone E J (ed) Yersinia enterocolitica, CRC Press, Boca Raton, FL, pp. 183-191.

Tsubokura M, Otsuki K, Kawaoka Y, Fukushima H 1982 Lysogenicity and phage typing of Yersinia enterocolitica isolated in Japan. Japanese Journal of Veterinary Science 44: 433-437.

Vandepitte J, Wauters G 1979 Epidemiological and clinical aspects of human Yersinia enterocolitica infections in Belgium. Contributions to Microbiology and Immunology 5:150-158.

Wauters G 1970 Contribution a l'étude de Yersinia enterocolitica. PhD Thesis Louvain, (Vander) Belgium.

Zen-yoji H 1981 Epidemiological aspects of yersiniosis in Japan. In: Bottone E J (ed) Yersinia enterocolitica, CRC Press, Boca Raton FL, pp. 205-216. 